\title{
Case on High Employee Absenteeism in Training Program -Prakash Manufacturing Ltd
}

\author{
Avinash K Singh ${ }^{1 *}$ and Suruchi Pandey ${ }^{2}$ \\ ${ }^{1}$ Student, Symbiosis International University, India \\ ${ }^{2}$ Faculty, Symbiosis International University, India
}

Submission: October 17, 2016; Published: December 01, 2016

*Corresponding author: Avinash K Singh, Student, Symbiosis International University, Pune, Maharashtra, India, Email: avinash.ksingh2017@sims.edu

\section{About the company}

Prakash Manufacturing ltd. was established in 1910 and turn into a self-governing traded on an open market organization in 1998. It was the first organisation in the America to deliver fluid nitrogen from air by the cryogenic chemical methods and turn into a leading innovator of technology in the business of industrial manufacturing gases.

It began its operational business in Indian market in 2000 through a Joint Venture along with Mindal Steel ltd. It had set up one of the biggest modern air separation plant in Chakan region, Maharashtra. Today, Prakash manufacturing ltd is one of the leading players of industrial gases supplier in India, with more than twenty five operational locations, an impressive list of clients and a national distribution network. Its products line in the similar products operation are atmospheric liquid gases like argon, nitrogen, oxygen and processes gases like $\mathrm{CO} 2$, electric Gases and speciality gases. It caters to a various group of industries are petroleum refining, manufacturing, beverage, steelmaking, aerospace and chemicals.

\section{Business Operation}

Prakash Manufacturing ltd has diversified their business operation in industrial gases product, gases distribution and R\&D.

\section{Industrial gases products}

Industrial gasses are the largest volume items manufactured by Prakash over worldwide locations. With atmospheric air as the primary raw material, it produces argon, nitrogen and oxygen by a few air separation procedures of which cryogenics air separation technique is the most predominant. Modern industrial gases, including carbon monoxide (CO), carbon dioxide (CO2), helium, hydrogen and speciality gasses are delivered by the techniques other than air separation.

\section{Industrial Gases Distribution}

In Industrial gases, Distribution channel are further classified into three methods are: (1) On-site (2) Bulk liquid (3) cylinder gases or packaged. This kind of dissemination techniques are incorporated, with product from three different supply means originating from the same unit. Furthermore, Prakash gives various different services, for example, maintenance of equipment, which is subsidiary to the process of supplying product to end customers.

\section{Research and development (R\&D)}

R\&D department is focussed towards growing unique and superior techniques for the creation and dispersal of modern gasses. It additionally directed to the advancement of new emerging markets and implementations for industrial gases. These outcomes in the improvement of new advanced air separation process, inventive nitrogen process technologies and regular initiation of the new modern industrial gas applications.

\section{Work culture}

Prakash manufacturing ltd has achieved its exceptional growth by employing and training the most skilled professionals who develop with the company and go on to become perfectionists in manufacturing industry. The company has highly people oriented goals with focused on employee safety first than work. It has always invested extensively on their employees training and development program.

At PML, employees are considered as an asset. As industrial gas involves a lot of risk while working at plant site, employee safety has been considered as a significant element of learning and development program. HR managers ensure that each employee has qualified their BSQ (Basic safety qualification) test with A+ grading. They work, have fun and even network with 


\section{Advances in Biotechnology \& Microbiology}

various professionals within similar product line industry. It is the culture of the organization to have a specific calendar for employee engagement activities which comply across various other locations.

PML is an open organization - means it is a company of learners and doers. Its culture fosters teamwork and defines success as working together to push each other employees to deliver best out of it. People are continually challenging one another to raise the benchmark of quality work. Learning and development department believes that their job is to connect employee with development opportunities that can help them to reach high on their career ladder. That's why company offer advanced classroom and external training, experiential and eLearning, and education reimbursement for job-related degree programs.

It has an unmatchable incentive structure. Management respect what employees do and totally understand that they deserve to be rewarded and acknowledged. Being a transparent organization, employees are trusted and important information is freely shared.

Here, Employees get an opportunity to brainstorm on various ideas, innovation thoughts and contribute to overall development of the organization. Also, company uses new-age, state-of-the-art technology and advanced cryogenic processes. One gets to learn about cutting-edge, innovative technique and productivity tools, which help the employees to not only become productive but also increase their technical know-how.

\section{The Problem}

Irrespective of having such a good training and development team, Prakash manufacturing ltd found that they have a repetitive training program from last 3 years and has also high employee absenteeism rate in training program.

It is clear that there is huge cost associated with training program including trainer cost, opportunity cost, travelling cost etc and, while some of these are not track or measure to the management information system. There is no effective analytics tool used by the L\&D mangers to administer and track employees training and development efforts.

Various other issues related to L\&D department are

\section{Inefficient training data management system}

HR managers maintain the data of training programs after 4-6 months.

It includes only few parameters of training program like name of program, total number of participants, date and total cost involved in it. Insufficient data available to take managerial decision. Departmental training cost cannot be determined based on the training data available.

\section{High employee absenteeism* in training program}

In PML, the training invitation program consists of four cycles. Initially, HR manager inform the functional manager and plant manager about the training programs. Then Plant manager communicates these messages to their sub ordinates and nominates someone to attend the training program. In the final stage, HR manager has to take follow up from plant as well as functional manager which consume a lot of time and employee turn up ratio for training program remains low.

It involves a lot of cost like trainer cost, travelling cost, productivity loss, opportunity cost etc which impact the return on investment of the training program.

(*Habitual failure to attend training program because of different reasons like official work, personal reason, client visit etc).

\section{Fewer participants from plant site}

Most of the cryogenic processes are simulated on the automation platform which require limited workforce. Employees work in the shift timing and some of the process require three shifts during the peak demand of industrial gases.

Such kind of industry requires advance level of training because any mistake from employees leads to heavy damage to the organization as well as environment. HR manager had been following the schedule of mandatory training and optional training but It had been observed that the number of respondents from each plant keep decreasing by the rate of $30 \%$ which results in cancellation of various programs.

\section{Lack of analytics tools}

Additionally, the PML has a difficulty keeping up with training need and had trouble of evaluation of feedback from the cross functional teams. Due to which training program was evaluated based on the observational method and there was no use of analytics tool to assess the performance of training program.

\section{Common Other Issues Experienced by HR} Department are

i. Ageing Workforce in the organization (Average age is 35-40 years).

ii. Gender diversification issue (Only 9\% female employee).

iii. Lack of strategic decisions while designing training calendar.

iv. Monotony of job \& few hiring for entry level position.

v. Small HR team Size (Less than 15).

\section{Questions}

1. What are some of the methods can be used for the effective assessment of training feedback and to measure the learning of participants?

2. How can HR help to reduce employee absenteeism in training program at Prakash Manufacturing Ltd? 
3. What strategic decisions will you take to improve the tracking and visibility of training data at Prakash Manufacturing ltd?

4. Suggest few initiatives to improve the gender diversification and ageing workforce issue in the organization.
5. Do you think analytics play an important role in training and development? If yes, as per you which all metrics are most effective today to bring quantification of the training parameters and how?

Your next submission with JuniperPublishers
will reach you the below assets
- Quality Editorial service
- Swift Peer Review
- Reprints availability
- E-prints Service
- Manuscript Podcast for convenient understanding
- Global attainment for your research
- Manuscript accessibility in different formats
( Pdf, E-pub, Full Text, Audio)
- Unceasing customer service
Track the below URL for one-step submission
http://juniperpublishers.com/online-submission.php

